Срешко Ю.О.

канд. економ. наук, доцент

Національний технічний університет Украӥни «КПI»

\title{
ЕКОНОМІЧНА СУТНІСТЬ ІНТЕЛЕКТУАЛЬНОГО КАПІТАЛУ ЯК ФАКТОРА ІННОВАЦІЙНОГО РОЗВИТКУ ЕКОНОМІКИ
}

\author{
ЭКОНОМИЧЕСКАЯ СУЩНОСТЬ ИНТЕЛЛЕКТУАЛЬНОГО КАПИТАЛА \\ КАК ФАКТОРА ИННОВАЦИОННОГО РАЗВИТИЯ ЭКОНОМИКИ
}

\author{
ECONOMIC ESSENCE OF AN INTELLECTUAL CAPITAL AS THE \\ ECONOMY'S INNOVATIVE DEVELOPMENT FACTOR
}

Виходячи із ичиклічного характеру розвитку економіки, а відтак, потреби у постійному пошуку факторів за межами виробничих можливостей з метою подолання деструктивності та переходу до нового, більшого за своїми можливостями, ичиклу, доведено необхідність інноваційності економічного зростання з метою досягнення системою сталого розвитку. Обтрунтовано економічну природу інтеллектуального капіталу як фактору інноваційного розвитку економіки.

Ірунтуючись на аналізі досліджень класичних політекономістів, неокласиків та інституціоналістів, визначено економічну сутність інтелектуального капіталу як здатності людей, використовуючи особистий фактор виробниџтва, вірніше його частину, - знання та інтелект, генерувати уречевлений. А також, обтрунтовано місие інтелектуального капіталу в системі продуктивних сил суспільства - його особливість одночасної приналежності і до нематеріальної (як форми розвитку індивіду), так $i$ до метеріальної (прикладних знань) сфери.

Зважаючи на мультихарактерність знань, доведено доцільність використання конщепції інтелектуального капіталу з метою конкретизації їх економічного змісту та управління ними. Проаналізовано економічні дослідження інтелектуального капіталу, яким властивий управлінських аспект і з'ясовано, щуо вони, переважно, зводяться до оцінки та моніторингу, щзо використовуються, здебільшого, в якості індикатору прогресу економіки знань, або інструменту коригування стратегій розвитку.

Структуризація знань в розрізі інтелектуального капіталу, дає підставу для припущення про підвищення ефективності управління знаннями на мікрорівні внаслідок ефективізачії даного процесу на макрорівні. Таким чином, можна зробити висновок про доцільність розробки механізму та удосконалення теорії управління інтелектуальним капіталом в різних розрізах економічної системи.

Ключові слова: інтелектуальний капітал, інновації, знання, економіка знань, сталий розвиток, інноваційний розвиток

Исходя из ичиклического характера развития экономики, а следовательно потребности в постоянном поиске факторов производства вне производственных возможностей с иелью преодоления деструктивности и перехода к новому, большему по своим возможностям, ииклу, доказана необходимость инновационности экономического роста на пути к достижению стабильного развития. Обоснована экономическая природа интеллектуального капитала как фактора инноваџионного развития экономики. 
Проведенный анализ исследований классических политэкономистов, неоклассиков и институционалистов позволяет определить экономическую сущуноть интеллектуального капитала как способности людей, используя личностный фактор производства, вернее его часть, - знания и интеллект, генерировать овеществленный. А также, обосновано место интеллектуального капитала в системе продуктивных сил - его особенность одновременной принадлежности и к нематериальной (как формы развития индивида), и к материальной (прикладные знания) сфере.

Ввиду мультихарактерности знаний, доказана целесообразность использования концепџии интеллектуального капитала с целью конкретизачии их экономического содержания и управления ими. Проанализировань экономические исследования интеллектуального капитала, которым свойственен управленческий аспект, и определено, что они в основном сводятся $\kappa$ оценке и мониторингу, которые используются как индикатор прогресса экономики знаний, либо инструмент корректировки стратегий развития.

Структуризаџия знаний в разрезе интеллектуального капитала дает основу для предположения о повышении эффективности управления знаниями на микроуровне вследствие эффективизации данного процесса на макроуровне. Таким образом, следует вывод о иелесообразности разработки механизма и усовершенствования теории управления интеллектуальным капиталом в разных разрезах экономической системь.

Ключевые слова: интеллектуальный капитал, инновации, знания, экономика знаний, устойчивое развитие, инновационное развитие

Based on the cyclical nature of the economy development, and therefore the need for constant search for the factors of production outside the production capacity to overcome the destructiveness and transition to a new cycle, larger in its capabilities, there proven the necessity of innovative economic growth on the way to a sustainable development. The economic nature of the intellectual capital as the factor of innovative development of economy was grounded.

Based on the classic politeconomists, neoclassics and institutionalists groundwork analysis, there was defined the economic essence of the intellectual capital as a people's capacity, using the personal factor of production, rather part of it - the knowledge and intellect, to produce objectified factors. Also, there was justified the place of an intellectual capital in a system of productive forces - its feature of simultaneous affiliation to an immaterial (as a form of individual development), as far as to a material (applied knowledge) sphere.

In a view of multi-specificity of knowledge, there was proven the expediency of using the intellectual capital concept in order to concretize their economic content and managing. There were analyzed the economic studies of intellectual capital peculiar to administrative aspect and there was defined that they are largely focused on to an assessment and monitoring, usually used as an knowledge economy growth indicators or as an adjustment tool of development strategies.

Knowledge structuring in an intellectual capital cut provides a basis to assume that the knowledge management efficiency improvement at the micro level is the result of this process effectivization at at the macro level. Therefore follows a conclusion on the advisability of development of a mechanism and improving the theory of the intellectual capital management in a different cuts of an economic system.

Key words: intellectual capital, innovations, knowledge, knowledge economy, sustainable development, innovative development 
Вступ. Сталий розвиток країни в довгостроковій перспективі, залежить, передусім, від iї здатності до продукування інновацій, що, в свою чергу, значною мірою виявляється в ефективності управління знаннями.

Дослідження Світового банку свідчать, що структура національного багатства розвинених країн виглядає, в середньому, так: фізичний капітал $16 \%$, природний капітал - $20 \%$, людський капітал - 64\%. В Японії і Німеччині останній показник досягає $80 \%$ [11]. До того ж, розвинені країни мають показник зайнятості населення у сфері науки і технологій - понад $25 \%$, та сукупний обсяг інвестицій кожної у знання переважає в середньому 9\% від ВВП.

За даними Глобального інноваційного індексу, Україна займає 14 місце в Світі за рівнем продукування знань, 25 - за рівнем освіти, 15 - за рівнем ефективності інновацій, проте лише 64 за загальним рівнем інновативності економіки [5].

Отже, активний розвиток фундаментальної науки, розвинута наукова база і, навіть, достатня ефективність інновацій не дають гарантії інноваційного розвитку економіки. Таким чином, постає проблема управління знаннями 3 метою перетворення людського потенціалу у реальний продуктивний фактор розвитку. В якості основного підходу до конкретизації знань з економічної точки зору, а, відтак, вибудови підгрунтя в управлінні ними використовують концепцію інтелектуального капіталу.

Проблематика управління знаннями знайшла своє відображення в працях таких вчених, як: Г. Беккер, Дж. Гелбрейт, П. Друкер, Л. Едвінссон, К. Гріффін, Г. Кант, М. Маллоун, К. Маркс, Ф. Махлуп, У. Петті, Д. Рісмен, А. Сміт, Р. Солоу, Е. Тоффлер, У. Хадсон, Д. Шнайдер, Й. Шумпетер, Т. Шульц, I. Крейдич, В. Семиноженко, Л. Федулова, Г. Яловий та ін.

Грунтовність досліджень вищезгаданих авторів, а також, сучасний рівень розвитку теорії факторів виробництва дає можливість здійснити глибокий аналіз економічної сутності інтелектуального капіталу з метою подальшої розробки ефективного механізму управління знаннями у вітчизняних реаліях.

Постановка завдання. Метою дослідження $€$ обгрунтування ролі інтелектуального капіталу у забезпеченні інноваційного розвитку економіки та дослідження його економічної природи, сутності і структури.

Методологія. Дослідження виконано 3 використанням діалектичних порівнянь, синтезу, проекції, моделювання та інших загальнонаукових та спеціальних методів пізнання.

Результати дослідження. Циклічний характер розвитку економіки зумовлює потребу у пошуку та/або генерації факторів і засобів за межею граничних іiі можливостей з метою подолання деструкцій, безумовно властвих кожній системі, що дасть поштовх до переходу до нового, вірніше новітнього, більшого за своїми можливостями циклу розвитку. За К. Марксом, потреба у впровадженні науково-технічних розробок i технологій, іншими словами 
інноваційному розвитку, стає наріжною за умови неможливості створення або примноження додаткової вартості за рахунок інтенсифікації праці, подовження робочого дня, залучення дешевшої робочої сили тощо [2]. На думку Й. Шумпетера - фактичного “батька” поняття “інновації”, що розглядав їх як нові комбінації використання ресурсів, зміни у технологіях та управлінні, - власне змістом кетегорії "розвиток" $є$ “впровадження нових комбінацій" [9]. М. Д. Кондратьєв зазначав: "Перед початком висхідної хвилі кожного великого циклу, а іноді і на самому його початку, спостерігаються значні зміни ... Ці зміни зазвичай виражаються в глибоких змінах техніки виробництва і обміну (яким, в свою чергу, передують значні винаходи та відкриття)" [1].

Таким чином, поштовхом до інноваційного розвитку стає по-перше: деструктивність економіки, як цілісної системи, по-друге: діалектична єдність протидії двох основних об'єктивних законів, що формулює, з рештою, головну мету економічних вчень - пошук максимально можливого задоволення необмежено зростаючих потреб суспільства в умовах обмеженості ресурсів, по-третє: постійні зміни навколишнього середовища i, як наслідок, альтернація економічних умов життєдіяльності людства.

Отже, інноваційність розвитку являє собою, фактично, намагання системи побороти власну деструктивність та подолати поріг ефективності, що $\epsilon$ логічною її властивсітю.

Кажучи про інновації, буде докорінно невірним ототожнювати їх із винаходами, розробками або нововведеннями. Наприклад, нововведення, на думку Й. Шумпетера, самі по собі не є економічними факторами [8]. Одночасно із цим, хоча високий розвиток фундаментальної науки і людського капіталу - джерел інновацій, не може гарантувати інноваційності зростання, більшість неоіндустріальних економік світу характеризуються значною наукоємністю, розвинутою науковою базою та високими показниками виробництва інноваційного продукту. Таким чином, мова йде про правильне перетворення людського потенціалу у реальний фактор економічного зростання.

Однією із властивостей сучасної розвиненої економіки є переважання зайнятості населення у нематеріальній сфері, тобто саме неоіндустріальна економічна система, а також, посилення ролі нематеріальних компонентів продукції: наукоємність високотехнологічного виробництва i, почасти, активна залежність обсягів реалізації “простого" товару від інтелектуальної складової підприємства: іміжду, брендів, репутації, компетенції співробітників, піару тощо. Таким чином, можна висунути припущення про актуальність економіки знань - економіки, де інновації та інтелектуальний капітал відіграють домінуючу роль у економічному розвитку.

Для розуміння економічної сутності інтелектуального капіталу, належить дослідити його місце в системі продуктивних сил суспільства. Ще за часів фізіократів, вченими виділено два основних фактори виробництва - землю і 
робочу силу. В процесі еволюції економічних вчень і предмета економічної теорії, еволюціонує, власне, і концепція продуктивних сил: так, Ж. Б. Сей виділяє вже капітал, землю і робочу силу, Дж. Б. Кларк додає підприємницькі здібності до “Сеєвої трійки”, а Ф. Махлуп, вживаючи вперше термін “економіка знань”, надає знанням значення головного і вирішального фактору суспільного виробництва і економічного зростання [3].

До того ж, наука i знання займають окреме місце в структурі виробництва: як форма розвитку індивіда і його соціальної свідомості, належать до нематеріальної сфери, а в якості продуктивної сили (прикладних знань) - до матеріальної. В процесі праці, людина перетворює навколишню природу у своїх інтересах, одночасно перетворючи і власну, внутрішню природу, накопичуючи знання і навички, що генерує суспільний розвиток. Разом 3 тим, революційним елементом продуктивних сил залишається уречевлений фактор суспільного виробництва - засоби виробництва, що швидко змінюються і еволюціонують 3 розвитком людини. Саме еволюція засобів виробницва і являє собою інновації, що стали «уречевленими знаннями». На наш погляд, саме здатність людини, використовуючи особистий фактор виробництва, вірніше його частину, - знання та інтелект, генерувати уречевлений - інновації, і є інтелектуальним капіталом.

Мультихарактерна природа знань та системна неоднорідність вирізняє їх 3-поміж "традиційних" економічних факторів. Так, частина знань не може бути відокремленою від їх носія, або не піддається копіюванню, інші, навпаки, активно і вільно тиражуються. Таким чином, використовуючи концепцію інтелектульного капіталу, в розрізі його структури, видається можливим конкретизувати економічний зміст знань, а саме:

- людський капітал - знання, невідокремлювані від людини-носія (вміння, навички, досвід, ноу-хау тощо), потенціал генерації знань людиною. Вимірює якість використання людського потенціалу через креативність та інновативність;

- структурний капітал - знання, що забезпечують умови функціонування людського капіталу (культура, звичаї, бази даних, процеси, патенти, авторські права, торгові марки, інформаційні системи, організаційна структура, корпоративна культура тощо). Через багатогранність структурного капіталу, виділяють також його елементи: організаційний, процесний та інноваційний капітал;

- споживчий капітал - знання, що виникають в процесі економічних відносин (ринкові відносини, відносини власності, кооперація, репутація серед клієнтів, імідж тощо).

На сьогодні, управління інтелектуальним капіталом зосереджене, переважно, на мікрорівні - існує множина теорій і концепцій, стратегій управління, застосовуваних організаціями різного роду. Проте, структуризація знань в розрізі інтелектуального капіталу дає підставу припустити, що 
ефективність управління ними окремим суб'єктом, залежить від ефективності управління загальним інтелектуальним капіталом країни.

Інтелектуальні ресурси країни є результатом взаємодії всієї сукупності суб'єктів, тому, теорія управління інтелектуальним капіталом має спиратись, передусім, на створення сприятливих умов для генерації знань, обміну знаннями та перетворення знань на прикладні інновації.

Перші спроби управління знаннями здійснювались ще за класиків, переважна більшість досліджень не мала на меті управління інтелектуальним капіталом, а радше, стосувалася його оцінки з різних позицій та, зазвичай, для демонстрації досягнень в області економіки знань. До прикладу, дослідження Міністерства промисловості, торгівлі і зайнятості Ізраїлю “Інтелектуальний капітал держави Ізраїль: 60 років досягнень" [10], описує елементи інтелектуального капіталу через сукупність індикаторів, залишаючи простір для подальшого аналізу.

Більш пізні вчення починають досліджувати інтелектуальний капітал 3 позиції економіки в цілому - як фактор інноваційного розвитку. Так, на думку Дж. Шиуми та А. Лерро, інтелектуальний капітал - це знання “неявні і кодифіковані”, і лежать в основі інноваційного розвитку, виступаючи його основою [7].

Схоже трактування лежить в основі моделі міжнародної дослідницької групи 3 оцінки і управління інтелектуальним капіталом "Arbeitskreis Wissensbilanz": інтелектуальний капітал $\epsilon$ ресурсом, що впливає на регіональні/національні бізнес-процеси [4]. Вихідним пунктом аналізу інтелектуального капіталу за даної моделі $\epsilon$ визначення цілей розвитку економіки. Далі, визначаються найбільш значимі елементи інтелектуального капіталу і здійснюється їх декомпозиція на більш елементрані частини. Таким чином, встановлюються управлінські взаємозв'язки між цілями системи та елементами інтелектуального капіталу. Далі відбувається оцінка стану елементів і відповідне коригування стратегії розвитку системи. Загалом, така модель $\epsilon$ достатньо перспективною для застосування у подальших дослідженнях в теорії управління інтелектуальним капіталом економіки в цілому.

Насправді, поняття інтелектуального капіталу у сучасному розумінні та теорії управління знаннями з'явилося відносно нещодавно, на прикінці XX ст., завдяки шведському економістові Л. Едвінссону -Л. Едвінссон і М. Маллоун вважаються піонерами економічної думки 3 теорії інтелектуального капіталу. На сьогодні, не існує єдиної концепції управління інтелектуальним капіталом як на мікро-, так і на макрорівні, а дослідження, що мають управлінський аспект, часто зводяться до оцінки інтеллектуального капіталу, що використовується, здебільшого, в якості індикатору прогресу економіки знань, або інструменту коригування стратегій розвитку. 
Висновки. Сучасний стан розвитку світової економіки впевнено доводить необхідність продукування інновацій, інноваційного характеру цього розвитку. Економіка будь-якого рівня - результат синергії членів суспільства, рівня розвитку їх продуктивних сил, що залежить, в свою чергу, від ефективності управління знаннями. Здатність людини до продукування реальних уречевлених у засобах виробництва знань, $\epsilon$ інтелектуальним капіталом, власне, людини, організації, економіки в цілому. Людський фактор відіграє, останнім часом, все більшої ролі розвитку економіки, що пояснюється активною інформатизацією, соціалізацією “без кордонів”. Таким чином, є підстава вести мову про інтелектуальний капітал як джерело інноваційного розвитку.

3 іншого боку, знання стають інтелектуальним капіталом, ліше за умови їх матеріалізації, появи властивостей революційного впливу на навколишнє середовище. Отже, з'являється безпосередня проблема в управлінні не тільки знаннями, особистими, а і знаннями уречевленими.

Переважна більшість досліджень 3 управління інтелектуальним капіталом зводиться до, власне, аналізу і моніторингу його стану, не пропонуючи апарату управління. Таким чином, очевидною стає потреба у разробці механізму та удосконаленні теорії управління інтелектуальним капіталом в якості наступного етапу дослідження даної проблематики.

Науковою новизною дослідження $€$ переосмислення поняття “інтелектуальний капітал” i виокреслення напрямків розробки механізму управління ним.

\section{Література:}

1. Кондратьев Н.Д. Большие циклы конъюнктуры и теория предвиденья: Избранные труды/Международный фонд Н.Д. Кондратьева и др. - М.: Экономика, 2002. - 767c.

2. Маркс К. Критика политической экономии / К.Маркс, Ф.Энгельс // Сочинения. . - 2-е изд. - М., 1968. - Т. 46.ч.I. - С. 256-301.

3. Федулова Л.І. Економіка знань: підруч. [для студ. вищ. навч. закл.] / НАН України; Ін-т екон. та прогнозув. НАН Україн. - К., 2009. - 600 с.

4. Alwert K., Bornemann M., Will M. et al. Wissensbilanz - Made in Germany: Leitfaden zur Erstellung einer Wissensbilanz. [Електронний pecypc]. Режим доступу: http://www.akwissensbilanz.org/Infoservice/Infomaterial/WB-Leitfaden_2.0.pdf

5. GII Annual Report 2015 [electronic source]: https://www.globalinnovationindex.org/content/page/gii-full-report-2015/\#pdfopener

6. Edvinsson, Leif, and Michael S. Malone. Intellectual Capital: Realizing Your Company's True Value by Finding Its Hidden Brainpower. (1997).

7. Schiuma G., Lerro A., Knowledge-based dynamics of regional development: the intellectual capital innovation capacity model // International journal of Knowledge-based Development, Vol. 1, 2010. - P. 39-52.

8. Schumpeter J.A. Teorie der wirtschaftlichen Entwicklung. Berlin: Dunker\&Humblot, 1997. $-\mathrm{S} .88-110$

9. Schumpeter J. The Theory of Economic Development. Cambridge; Harvard, 1934 
10. The Intellectual Capital of State Israel: 60 years of achievments. Режим доступу: http://www.moital.gov.il/ic

11. World Bank Annual Review of Development Effectiveness 2008 : Shared Global Challenges Annual Review of Development Effectiveness 2008 : Shared Global Challenges https://openknowledge.worldbank.org/handle/10986/6553 